Article

\title{
Synthesis and catalytic oxidation performance of Al-TS-1
}

\author{
SHEN Lu, DENG Xiujuan, LIU Yueming* \\ Shanghai Key Laboratory of Green Chemistry and Chemical Processes, Department of Chemistry, East China Normal University, Shanghai 200062, \\ China
}

A R T I C L E I N F O

Article history:

Received 14 January 2013

Accepted 29 January 2013

Published 20 June 2013

\section{Keywords:}

Al-TS-1 zeolite

Synthesis

Epoxidation

Desilication

Ammoximation

\begin{abstract}
A B S T R A C T
The preparation of titanium silicalite-1 (TS-1) containing Al (Al-TS-1) and its catalytic oxidation properties were investigated systematically. The features of Al-TS-1 were characterized using X-ray diffraction, ultraviolet-visible spectroscopy, inductively coupled plasma atomic emission spectroscopy, ${ }^{27} \mathrm{Al}$ magic-angle spinning and ${ }^{29} \mathrm{Si}$ magic-angle spinning nuclear magnetic resonance spectroscopies, and scanning electron microscopy. The results showed that incorporation of Al into the TS-1 framework influences the amount of framework Ti in Al-TS-1. However, when the Al/Si ratio is lower than 0.005, the amount of framework Ti in Al-TS-1 is hardly affected. Neither the Al centers nor the Ti centers in the Al-TS-1 framework influence the acidic catalytic and catalytic oxidation performance. Al in the Al-TS-1 framework suppressed desilication of silica species adjacent to framework Ti species in Al-TS-1 in a basic catalytic system, so Ti active sites in the Al-TS-1 framework could be protected.
\end{abstract}

(C) 2013, Dalian Institute of Chemical Physics, Chinese Academy of Sciences. Published by Elsevier B.V. All rights reserved.

\section{Introduction}

Titanium silicalite-1 (TS-1) is obtained by partial isomorphous substitution of Si in S-1. Since it was first reported in 1983 [1], it has been widely used in various organic catalytic processes using hydrogen peroxide as a mild oxidant [2-4]. It has been reported that the catalytic activity of TS- 1 is attributable to the framework Ti species in the TS- $1 / \mathrm{H}_{2} \mathrm{O}_{2}$ system. The framework tetrahedral $\mathrm{Ti}^{4+}$ ions interact with $\mathrm{H}_{2} \mathrm{O}_{2}$ to form active intermediates, and then active oxygen is transferred to the substrate to form the corresponding oxide [2,3,5-7]. The physicochemical properties of TS- 1 such as the coordination states of Ti species, surface acidity, hydrophobicity, and incorporation of heteroatoms into the TS-1 framework play a crucial role in its catalytic properties. Recently, many heteroatoms such as $\mathrm{Al}, \mathrm{B}$, and Fe have been incorporated into the TS-1 framework to form bifunctional catalysts [8-12]. In particular, Al-TS-1, with Al incorporated into the TS-1 framework, which has Brönsted acid sites, is a promising and excellent catalyst for the bifunctional catalysis of acidic reactions/oxidations such as alcohol etherification reactions [13-15]. However, the presence of Brönsted acid sites could result in side reactions of the oxide in the oxidation reaction [16-19].

It is worth noting that the main interest is the effect of framework $\mathrm{Al}$ and $\mathrm{Ti}$ atoms in the Al-TS-1 zeolite on the catalytic properties. Thangaraj et al. [9] reported that the low acitvity in hydroxylation reactions was related to decomposition of $\mathrm{H}_{2} \mathrm{O}_{2}$ as a result of the presence of $\mathrm{Al}$ in Al-TS-1, but it exhibited similar activity to that of ZSM- 5 in $m$-xylene isomerization reactions. It is concluded that Ti in Al-TS-1 does not influence the acid catalytic properties, but the presence of $\mathrm{Al}$ decreases its catalytic performance in oxidation reactions.

\footnotetext{
*Corresponding author. Tel/Fax: +86-21-62232058; E-mail: ymliu@chem.ecnu.edu.cn

This work was supported by the National Natural Science Foundation of China (20973064), the National Key Technology R\&D Program (2012BAE05B02), the Science and Technology Commission of Shanghai Municipality (12JC1403600), and the Shanghai Leading Academic Discipline Project (B409). 
Ovejero et al. [15] thought that the catalytic oxidation activity increased because the presence of $\mathrm{Al}$ changed the surface hydrophobicity when the $\mathrm{Al} / \mathrm{Si}$ ratio in $\mathrm{Al}-\mathrm{TS}-1$ was 0.70 . It is therefore not clear whether the framework $\mathrm{Al}$ influences the catalytic oxidation of framework Ti. We have therefore studied the synthesis of Al-TS-1, and performed a detailed study of the physicochemical properties and catalytic oxidation performance of Al-TS-1. The study showed that the framework Al species in Al-TS-1 have no influence on the catalytic oxidation properties originating from framework $\mathrm{Ti}$, and vice versa. It was also found that the presence of Al inhibits desilication adjacent to framework Ti species in the ammoximation of cyclohexanone catalyzed by Al-TS-1. In addition, our study may provide information for designing highly stable TS-1 zeolites in basic reaction systems.

\section{Experimental}

\subsection{Preparation and characterization of Al-TS-1}

Al-TS-1 samples with different $\mathrm{Al}$ contents were synthesized using a hydrothermal method [20,21]. First, a specific amount of aluminum isopropoxide [AIP, analytical reagent (AR) grade; Sinopharm Chemical Reagent Co., Ltd.] was added to tetrapropylammonium hydroxide (TPAOH, $25 \mathrm{wt} \%$, industrial product) aqueous solution. This was followed by the slow addition of a mixture of tetraethoxysilane (TEOS, AR; Sinopharm Chemical Reagent Co., Ltd.) and tetrabutyl titanate (TBOT, AR; Shanghai LingFeng Chemical Reagent Co., Ltd.). The resulting mixture was crystallized at $170{ }^{\circ} \mathrm{C}$ for $48 \mathrm{~h}$ after hydrolyzing and removing the alcohol. The product was separated by filtration, washed with distilled water, dried overnight, and calcined. The molar ratios of the raw materials were TEOS:TBOT:AIP: TPAOH: $\mathrm{H}_{2} \mathrm{O}=1: 0.0167:(0.001-0.0167): 0.18: 18$.

Synthesis of TS-1: except for the addition of AIP, the procedure was the same as that for Al-TS-1.

The crystalline phase was determined using X-ray diffraction (XRD; Bruker D8 ADVANCE; $\mathrm{Cu} \mathrm{K}_{\alpha}$ radiation, scanned area $2 \theta=5^{\circ}-35^{\circ}$ ). The Ti coordination states of the catalysts were investigated using ultraviolet-visible (UV-Vis) spectroscopy (Shimadzu UV-2550, $\mathrm{BaSO}_{4}$ as the reference). The $\mathrm{Al}$ and $\mathrm{Si}$ coordination states of the catalysts were determined using magic-angle spinning nuclear magnetic resonance (MAS NMR) spectroscopy. The $\mathrm{Ti}$ and $\mathrm{Al}$ contents were measured using inductively coupled plasma atomic emission spectroscopy (ICP-AES; Thermo IR ISIntrepid II). The morphologies and sizes of the crystallites were determined using high-resolution field-emission scanning electron microscopy (SEM; Hitachi S-4800).

\subsection{Epoxidation of 1-hexene}

The liquid-phase epoxidation of 1-hexene with $\mathrm{H}_{2} \mathrm{O}_{2}$ was carried out at $60^{\circ} \mathrm{C}$ for $2 \mathrm{~h}$, with stirring, in a batch reactor consisting of a round-bottomed flask $(50 \mathrm{ml})$ equipped with a condenser. The reaction mixture was as follows: $0.05 \mathrm{~g}$ of catalyst, $10 \mathrm{ml}$ of methanol as solvent, $10 \mathrm{mmol}$ of 1 -hexene, and 10 mmol of $\mathrm{H}_{2} \mathrm{O}_{2}$ ( $\sim 30 \mathrm{wt} \%$ aqueous solution) as the oxidant. The product was analyzed using gas chromatography (GC; Agilent GC7890A gas chromatograph equipped with a $30 \mathrm{~m} \times 320 \mu \mathrm{m} \times$ $0.25 \mu \mathrm{m}$ DB-WAX capillary column). The amount of unconverted $\mathrm{H}_{2} \mathrm{O}_{2}$ was determined by titrating with $0.05 \mathrm{~mol} / \mathrm{L}$ $\mathrm{Ce}\left(\mathrm{SO}_{4}\right)_{2}$ aqueous solution.

\subsection{Ammoximation of cyclohexanone}

The liquid-phase ammoximation of cyclohexanone was conducted in a similar manner, except that the $\mathrm{H}_{2} \mathrm{O}_{2}$ was added within $90 \mathrm{~min}$ at a constant speed. The reaction conditions were as follows: $75^{\circ} \mathrm{C}, 2 \mathrm{~h}, 0.45 \mathrm{~g}$ of catalyst, $10 \mathrm{ml}$ of tert-butyl alcohol aqueous solution (tert-butyl alcohol, AR, $85 \mathrm{wt} \%$ ) as solvent, $30 \mathrm{mmol}$ of cyclohexanone (AR), $51 \mathrm{mmol}$ of $\mathrm{NH}_{3} \cdot \mathrm{H}_{2} \mathrm{O}$ (AR, $25 \mathrm{wt} \%$ ), and $33 \mathrm{mmol}$ of $\mathrm{H}_{2} \mathrm{O}_{2}(\sim 30 \mathrm{wt} \%$ aqueous solution). The product was analyzed on an Agilent GC7890A GC equipped with a $30 \mathrm{~m} \times 320 \mu \mathrm{m} \times 0.25 \mu \mathrm{m}$ DB-WAX capillary column.

\section{Results and discussion}

\subsection{Synthesis and characterization}

\subsection{1. $X R D$}

Figure 1 shows the XRD patterns of Al-TS-1 with different $\mathrm{Al} / \mathrm{Si}$ ratios. All the samples exhibit the typical diffraction peaks of an MFI-type structure. The relative crystallinities of all the Al-TS-1 samples are almost the same, so incorporation of $\mathrm{Al}$ into TS-1 has no influence on the crystallization of Al-TS-1 [14].

\subsubsection{UV-Vis spectra}

The Ti coordination state of Al-TS-1 was investigated using UV-Vis spectroscopy (Fig. 2). The bands at 210, 260, and 330 nm demonstrate that the Ti atoms exist in a tetrahedral coordination in the zeolitic framework, octahedral Ti species, and anatase, respectively [22]. There is a strong band at $210 \mathrm{~nm}$ for all the Al-TS-1 samples, in accordance with the literature $[11,15]$. It is worth noting that the peak intensity at $210 \mathrm{~nm}$ of

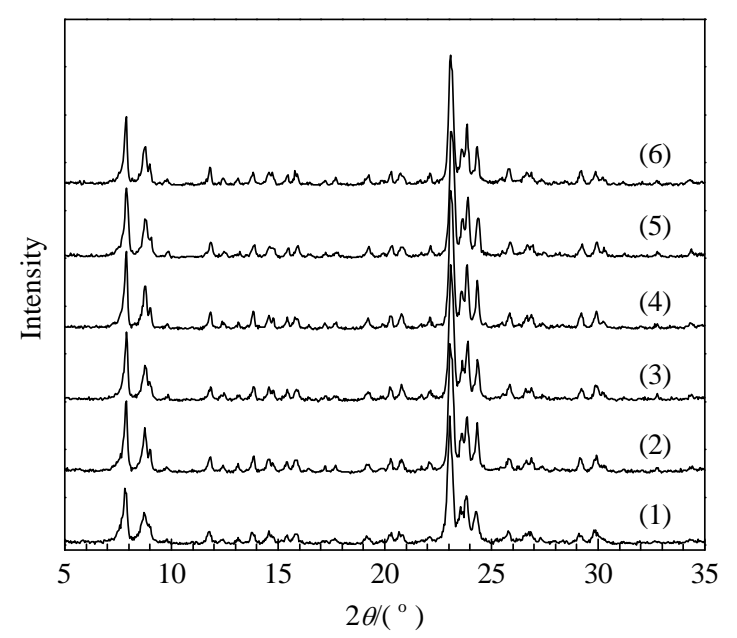

Fig. 1. XRD patterns of $\mathrm{Al}-\mathrm{TS}-1$ with different $\mathrm{Al} / \mathrm{Si}$ ratios. (1) 0.0167; (2) 0.01 ; (3) 0.005 ; (4) 0.002 ; (5) 0.001 ; (6) 0. 


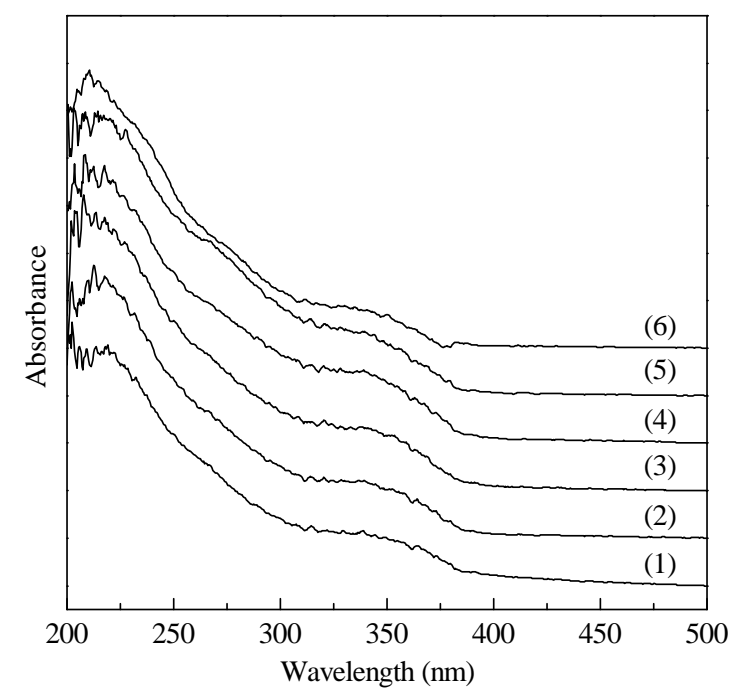

Fig. 2. UV-Vis spectra of Al-TS-1 $(\mathrm{Si} / \mathrm{Ti}=60)$ with different $\mathrm{Al} / \mathrm{Si}$ ratios. (1) 0.0167 ; (2) 0.01 ; (3) 0.005 ; (4) 0.002; (5) 0.001; (6) 0.

Al-TS-1 with $\mathrm{Al} / \mathrm{Si}>0.005$ is lower than that of Al-TS-1 with $\mathrm{Al} / \mathrm{Si} \leq 0.005$, even in normal TS-1 ( $\mathrm{Si} / \mathrm{Ti}=60)$ samples; that is, the amount of framework Ti species in Al-TS-1 is related to the amount of framework $\mathrm{Al}$ species in $\mathrm{Al}$-TS-1. In addition, anatase was found both in Al-TS-1 and TS-1 samples, and they also have the similar peak pattern. Consequently, we can conclude that the incorporation of $\mathrm{Al}$ into $\mathrm{Al}-\mathrm{TS}-1$ does not affect the distribution of framework Ti species in Al-TS-1.

\subsubsection{ICP-AES}

Figure 3 shows the $\mathrm{Ti} / \mathrm{Si}$ and $\mathrm{Al} / \mathrm{Si}$ ratios of $\mathrm{Al}-\mathrm{TS}-1$ synthesized with different $\mathrm{Al} / \mathrm{Si}$ ratios, and same $\mathrm{Si} / \mathrm{Ti}$ ratios $(\mathrm{Si} / \mathrm{Ti}=$ 60 in raw material) measured by ICP-AES. The results indicate that the $\mathrm{Ti} / \mathrm{Si}$ ratio in Al-TS-1 is nearly the same as that in normal TS- 1 when the $\mathrm{Al} / \mathrm{Si}$ ratio is lower than 0.005 , i.e., $\mathrm{Al}$ hardly influences the insertion of Ti into Al-TS-1. When the Al/Si ratio is higher than 0.005 , the $\mathrm{Ti} / \mathrm{Si}$ ratio decreases with increasing $\mathrm{Al}$ content, which shows that the insertion of $\mathrm{Al}$ inhibits Ti in-

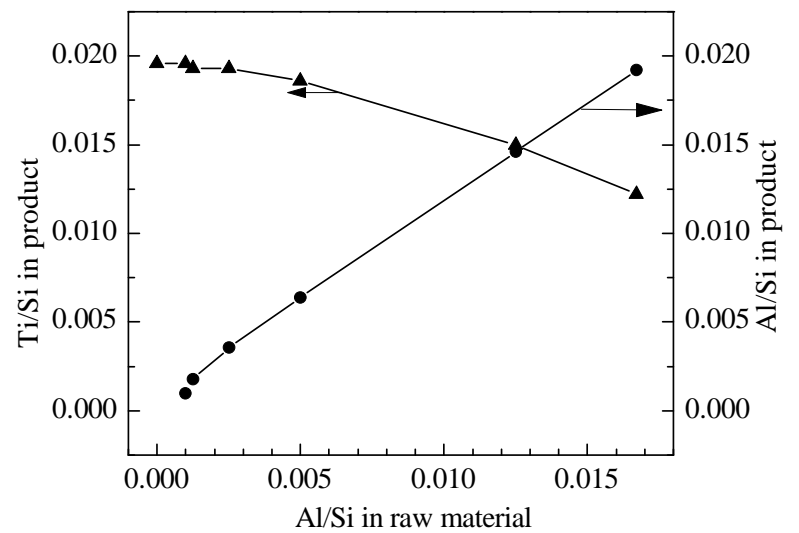

Fig. 3. $\mathrm{Ti} / \mathrm{Si}$ and $\mathrm{Al} / \mathrm{Ti}$ ratios of $\mathrm{Al}-\mathrm{TS}-1(\mathrm{Si} / \mathrm{Ti}=60)$ synthesized with different $\mathrm{Al} / \mathrm{Si}$ ratios.

sertion into the zeolitic framework. However, the $\mathrm{Al} / \mathrm{Si}$ ratio increases linearly with increasing $\mathrm{Al}$ content because incorporation of $\mathrm{Al}$ into the MFI-type framework is easier than insertion of Ti. During the synthesis of Al-TS- 1 at high $\mathrm{Al}$ contents, $\mathrm{Al}$ and Ti atoms compete for insertion into the Al-TS-1 framework. Too much framework Al species may prohibit incorporation of Ti into the Al-TS-1 framework, thus the Ti/Si ratio of Al-TS-1 is lower, as shown by the UV-Vis results $[11,15]$.

\subsubsection{SEM}

Figure 4 shows the SEM images of Al-TS-1 ( $\mathrm{Si} / \mathrm{Ti}=60)$ synthesized with different $\mathrm{Al} / \mathrm{Si}$ ratios. All the Al-TS-1 samples have an ellipsoid morphology similar to that of TS-1, but the particle size of Al-TS-1 is much larger than that of normal TS-1, The particle size of Al-TS-1 increases with the increase of Al. It is worth noting that the morphology of Al-TS-1 undergoes a significant change. The morphology of Al-TS-1 presents obvious agglomeration of small particles at high Al content, which shows that the presence of $\mathrm{Al}$ in the synthesis is beneficial to the formation of nuclei. These results are in agreement with those of Melero et al. [14] and Serrano et al. [23] regarding the effect of $\mathrm{Al}$ atoms on crystallization.

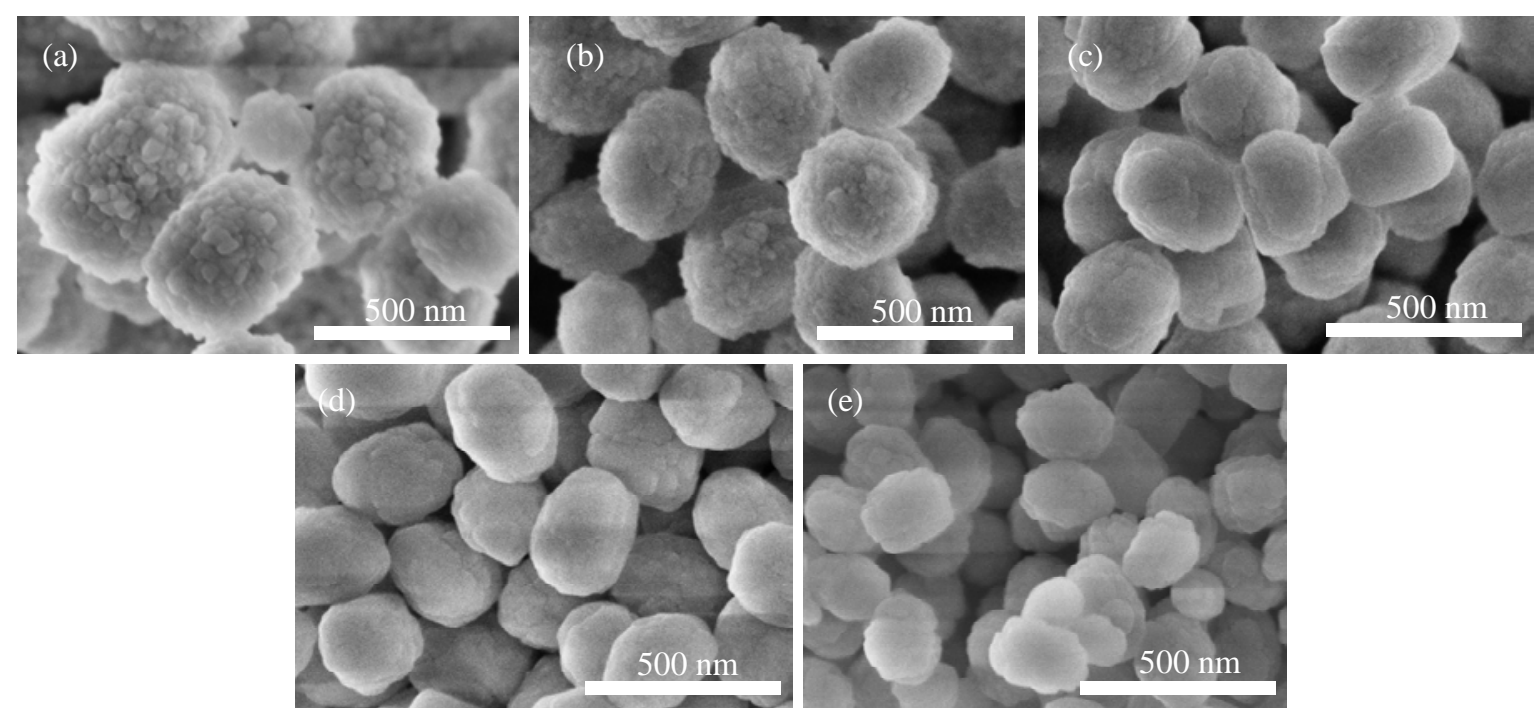

Fig. 4. SEM images of Al-TS-1 (Si/Ti = 60) synthesized with different Al/Si ratios. (a) 0.0167; (b) 0.01; (c) 0.0025; (d) 0.001 ; (e) 0 . 

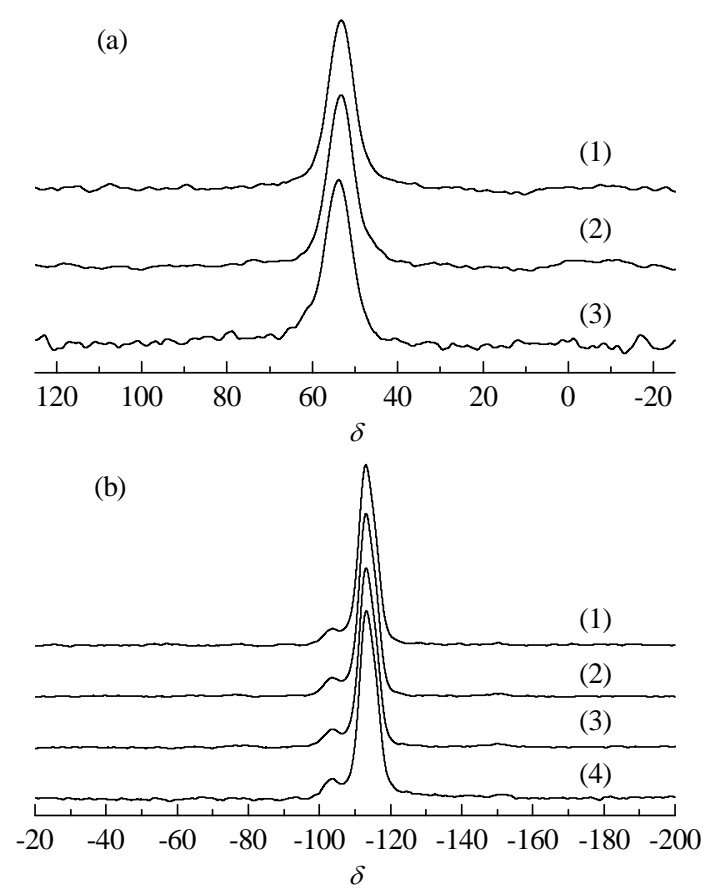

Fig. 5. ${ }^{27} \mathrm{Al}$ MAS NMR (a) and ${ }^{29} \mathrm{Si} \mathrm{MAS} \mathrm{NMR} \mathrm{(b)} \mathrm{spectra} \mathrm{of} \mathrm{Al-TS-1} \mathrm{(Si/Ti}$ = 60) synthesized with different $\mathrm{Al} / \mathrm{Si}$ ratios. (1) 0.0167; (2) 0.002; (3) 0.001; (4) 0 .

\subsection{5. ${ }^{27}$ Al and ${ }^{29}$ Si MAS NMR}

Figure 5(a) shows the ${ }^{27} \mathrm{Al}$ MAS NMR spectra of Al-TS-1 $(\mathrm{Si} / \mathrm{Ti}=60)$ synthesized with different $\mathrm{Al} / \mathrm{Si}$ ratios. Normally, the signal at $\delta=50$ is associated with $\mathrm{Al}$ atoms in tetrahedral environments in the framework, and the signal at $\delta=0$ is assigned to extra-framework Al species [15]. Figure 5(a) shows that all the Al-TS-1 samples have a similar tetrahedral coordination state belonging to $\mathrm{Al}$ in the framework; that is, $\mathrm{Al}$ atoms can be inserted into Al-TS-1 framework more easily than Ti atoms can $[11,15]$; this is in good agreement with the ICP-AES results. The ${ }^{29} \mathrm{Si}$ MAS NMR spectra of Al-TS-1 (Si/Ti = 60) samples synthesized with different $\mathrm{Al} / \mathrm{Si}$ ratios and normal synthesized TS-1 ( $\mathrm{Si} / \mathrm{Ti}=60)$ are depicted in Figure 5(b). The spectra clearly exhibits two broad features associated with $\mathrm{Q}^{3}(\delta=$ -95.0 to -104.0$)$ and $\mathrm{Q}^{4}(\delta=-104.0$ to -115.0$)$. The peaks in the $\mathrm{Q}^{3}$ region arise from a silanol group with three $\mathrm{T}-\mathrm{O}-\mathrm{T}$ ( $\mathrm{T}$ is Ti or $\mathrm{Si}$ ) groups, and those in the $\mathrm{Q}^{4}$ region are attributed to $\mathrm{Si}$ connected to four $\mathrm{T}$ atoms by $\mathrm{O}$ atoms. Therefore, $\mathrm{Si}$ species in Al-TS- 1 and TS- 1 exist mainly in the form of $\mathrm{Q}^{4}$ state. Furthermore, the amount of $\mathrm{Al}$ in Al-TS-1 is hardly related to the coordination state of $\mathrm{Si}$ in the framework. Al-TS-1 samples with different Al contents have similar hydrophobicities with TS-1 when they have the same Ti contents by analyzing $Q^{3}$ form.

\subsection{Catalytic activity of Al-TS-1}

\subsubsection{Epoxidation of 1-hexene}

Figure 6 shows the catalytic oxidation performances of Al-TS-1 samples synthesized with different $\mathrm{Al} / \mathrm{Si}$ ratios in the epoxidation of 1-hexene. Besides 1,2-epoxyhexane, the final products also include the alcohol ether produced by acid catalysis with the solvent. However, we did not detect

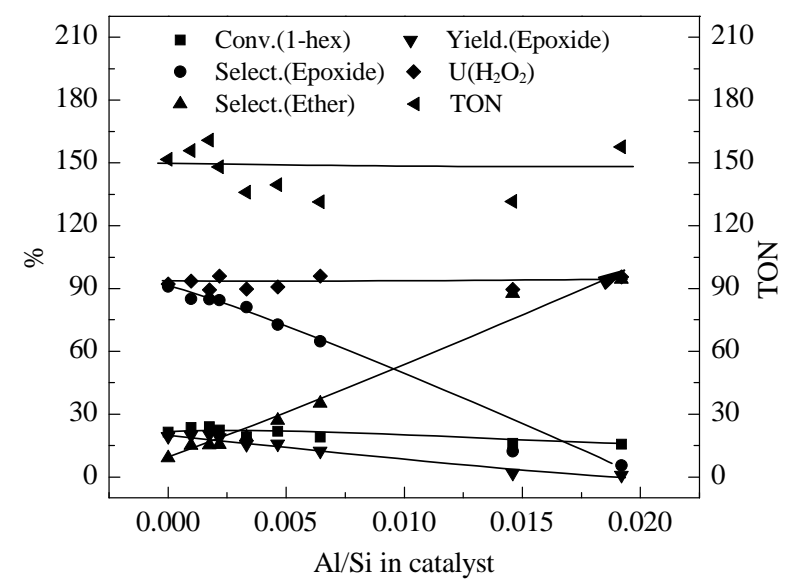

Fig. 6. Catalytic oxidation performance of Al-TS-1 synthesized with different $\mathrm{Al} / \mathrm{Si}$ ratios in epoxidation of 1-hexene.

1,2-hexanediol, which is the product of 1,2-epoxyhexane reacted with $\mathrm{H}_{2} \mathrm{O}$ in the existence of acid site. We consider that alcoholysis can proceed more easily than hydrolysis [16,24].

It can be demonstrated that the conversion of 1-hexene for all the samples was nearly invariant when $\mathrm{Al} / \mathrm{Si} \leq 0.005$. However, the conversion of 1-hexene decreased slightly with increasing $\mathrm{Al}$ content in Al-TS- 1 when the $\mathrm{Al} / \mathrm{Si}$ ratio was higher than 0.005 . This is because there are relatively small numbers of Ti species in Al-rich Al-TS-1. However, the turnover numbers (TON) of 1-hexene obtained over all the samples were high in each case, as well as the effective use of $\mathrm{H}_{2} \mathrm{O}_{2}$. This shows that the presence of $\mathrm{Al}$ in the framework does not influence the catalytic oxidation performance catalyzed by Ti active sites. Li et al. [19] have studied the effect of Al impurities on the epoxidation of propylene with TS-1. If a small amount of base is added to the TS-1 framework, side reactions can be inhibited and the propylene epoxide selectivity increases significantly. Therefore, although $\mathrm{Al}$ atoms have an effect on the incorporation of Ti into Al-TS-1 when the Al content exceeds a certain amount, framework Al species do not influence the catalytic oxidation performance originated by the Ti active sites. This is different from some of the results reported in the literature $[9,15]$. Thangaraj et al. [9], thought that $\mathrm{Al}$ species lead to decomposition of $\mathrm{H}_{2} \mathrm{O}_{2}$. However, the real reason may be that the amounts of extra-framework Ti species resulted in decomposition of $\mathrm{H}_{2} \mathrm{O}_{2}$. This is because Ti species cannot totally insert into the framework, and some extra-framework Ti species are present when $\mathrm{Si} / \mathrm{Ti}=24$ and $\mathrm{Si} / \mathrm{Al}=45$. However, Ovejero et al [15], believed that the presence of $\mathrm{Al}$ in $\mathrm{Al}-\mathrm{TS}-1$ samples modifies the activity for oxidation compared with that in TS-1, with an optimum $\mathrm{Al} / \mathrm{Ti}$ molar ratio of ca. 0.7 ; this seems to be related to changes in the hydrophilic/hydrophobic characters of the samples. However, we can conclude that Al-TS-1 with various Al contents and TS-1 have similar hydrophilic/hydrophobic characters from the results in Fig. 5(b), so the catalytic oxidation performance cannot be influenced greatly. The framework Al species therefore do not affect the catalytic oxidation performances of Ti centers in catalytic oxidation using Al-TS-1.

For the acid catalysis of Al-TS-1, originating from $\mathrm{Al}$ in the framework, the selectivity for the alcohol ether increased with 


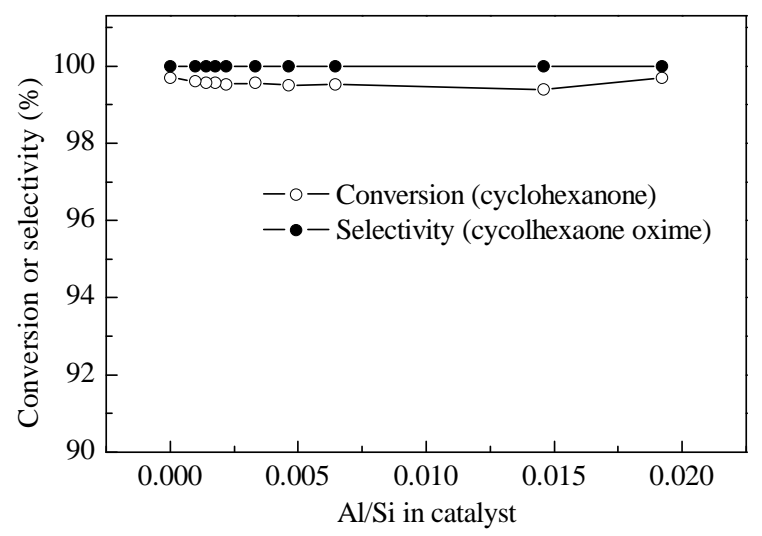

Fig. 7. Catalytic oxidation performances of Al-TS-1 synthesized with different $\mathrm{Al} / \mathrm{Si}$ ratios in ammoximation of cyclohexanone.

increasing $\mathrm{Al}$ content, whereas the selectivity of 1,2-epoxyhexane decreased. This shows that the presence of Ti in Al-TS-1 has no influence on its acidic catalytic performance, which is in accord with a previous report [9].

\subsubsection{Ammoximation of cyclohexanone catalyzed by Al-TS-1}

\subsubsection{Initial activity}

Figure 7 shows the catalytic properties of Al-TS-1 synthesized with different $\mathrm{Al} / \mathrm{Si}$ ratios in the ammoximation of cyclohexanone. The conversion of cyclohexanone and the selectivity for cyclohexanone oxime are the same for all the Al-TS-1 samples. This shows that incorporation of $\mathrm{Al}$ into the TS- 1 framework has no influence on the catalytic properties catalyzed by $\mathrm{Ti}$ active sites. This has the same conclusion as that reached for epoxidation of 1-hexene. This is because excess $\mathrm{NH}_{3}$ in the liquid system neutralizes the Brönsted acid sites originating from framework Al species [19], so the catalytic oxidation performance of Al-TS-1 stays well.

\subsubsection{Reusability of Al-TS-1 for ammoximation of cyclohexanone}

Figure 8 shows the reusability of Al-TS- 1 in the ammoximation of cyclohexanone when $\mathrm{Si} / \mathrm{Al}=100$ and $\mathrm{Si} / \mathrm{Ti}=60$. Al-TS-1

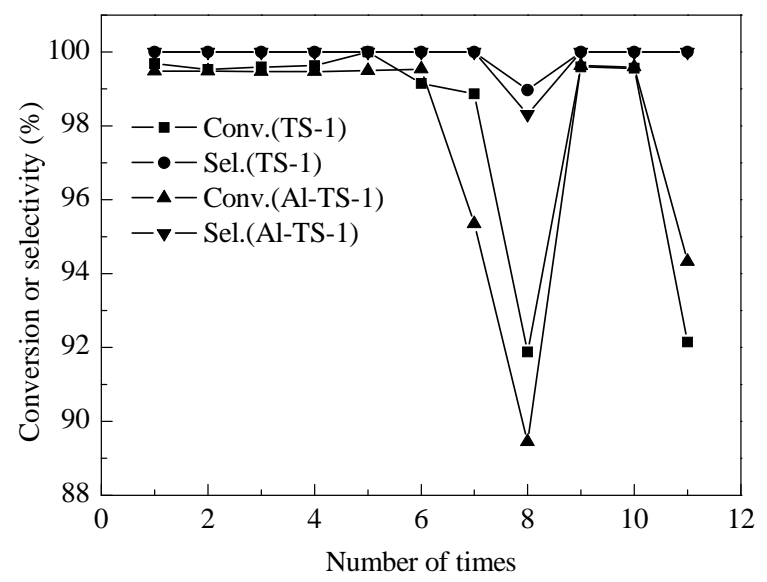

Fig. 8. Reusability of Al-TS-1 in ammoximation of cyclohexanone.

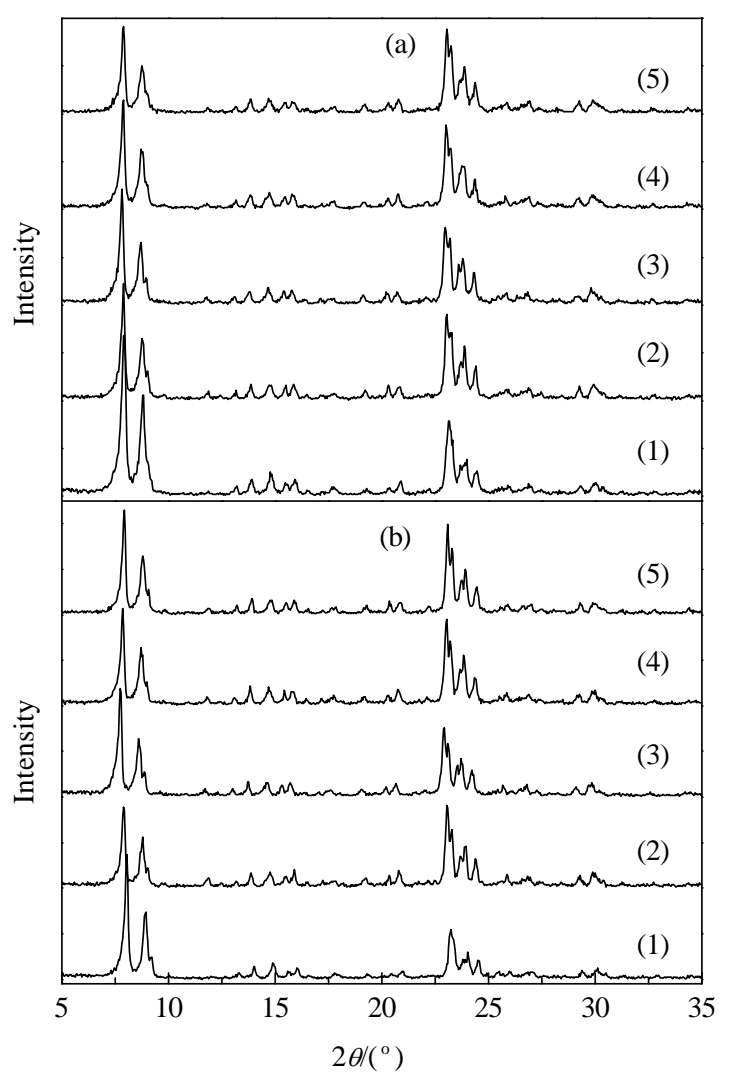

Fig. 9. XRD patterns of Al-TS-1 (a) and TS-1 (b) reused in ammoximation of cyclohexanone. (1) Fresh; (2) First; (3) Third; (4) Sixth; (5) Deactivated.

Table 1

Changes in $\mathrm{Si} / \mathrm{Ti}$ and $\mathrm{Si} / \mathrm{Al}$ ratios in reused TS-1 and Al-TS-1 measured by ICP.

\begin{tabular}{lcc}
\hline Sample & $\mathrm{Si} / \mathrm{Ti}$ & $\mathrm{Si} / \mathrm{Al}$ \\
\hline TS-1 & 51.1 & - \\
TS-1-resued & 52.1 & - \\
Al-TS-1 & 59.9 & 86.3 \\
Al-TS-1-used & 59.4 & 81.6 \\
\hline
\end{tabular}

and TS-1 (Si/Ti = 60) have highly catalytic oxidation performances. After being reused eight times, the activities of all the samples decreased, but the activity of the deactivated catalyst can be recovered to the initial activity by calcining at $550{ }^{\circ} \mathrm{C}$.

To analyze changes in structure of Al-TS- 1 and TS- 1 for ammoximation of cyclohexanone thoroughly, XRD and ICP-AES measurements were performed on Al-TS- 1 and TS- 1 showed in Fig. 9 and Table 1.

The XRD patterns of Al-TS-1 and TS-1 reused in the ammoximation of cyclohexanone are shown in Fig. 9. Both Al-TS-1 and TS-1 kept excellent MFI structures after being reused. Table 1 shows that the Si/Ti ratio of TS-1 increased from 51.1 to 52.1 after reuse, which showed that the rate of desilication was slower than that of $\mathrm{Ti}$ removal originated by desilication $[25,26]$. However, the Si/Ti ratio in Al-TS-1 varied from 59.9 to 59.4. This indicates that Ti removal during reuse was suppressed to some degree. In contrast, the $\mathrm{Si} / \mathrm{Al}$ ratio of Al-TS-1 after reuse decreased from 86.3 to 81.6. This means that desil- 
Table 2

$\mathrm{Si} / \mathrm{Ti}$ and $\mathrm{Si} / \mathrm{Al}$ ratios of different catalysts treated with $\mathrm{NaOH}$ measured by ICP.

\begin{tabular}{lcccc}
\hline Sample & $\begin{array}{c}\mathrm{Si} / \mathrm{Ti} \\
\text { (Untreated) }\end{array}$ & $\begin{array}{c}\mathrm{Si} / \mathrm{Al} \\
\text { (Untreated) }\end{array}$ & $\begin{array}{c}\mathrm{Si} / \mathrm{Ti} \\
\text { (Treated) }\end{array}$ & $\begin{array}{c}\mathrm{Si} / \mathrm{Al} \\
\text { (Treated) }\end{array}$ \\
\hline TS-1 & 54.9 & - & 52.3 & - \\
ZSM-5 & - & 55.8 & - & 52.1 \\
Al-TS-1 & 79.9 & 55.9 & 79.8 & 52.1 \\
\hline
\end{tabular}

Treatment conditions: $1 \mathrm{~g}$ of zeolite dissolved in $30 \mathrm{ml}$ of $\mathrm{NaOH}$ aqueous solution $(0.2 \mathrm{~mol} / \mathrm{L})$ at $65^{\circ} \mathrm{C}$ for $0.5 \mathrm{~h}$.

ication is much more extensive than dealumination originating from extraction of Si species. The Si species adjacent to $\mathrm{Al}$ in the Al-TS-1 framework are therefore more easily attacked by alkaline molecules than the $\mathrm{Si}$ species neighboring to $\mathrm{Ti}$, and this favors retention of the tetrahedral coordination state of $\mathrm{Ti}$ in the zeolitic framework.

\subsubsection{Dissolution rule of Si and Ti}

To confirm the rule for dissolution by alkali, TS-1, ZSM-5, and Al-TS-1 [27] were treated with $\mathrm{NaOH}$ aqueous solution. The changes of $\mathrm{Si} / \mathrm{Ti}$ and $\mathrm{Si} / \mathrm{Al}$ ratios were analyzed using ICP-AES. The results are shown in Table 2. The $\mathrm{Si} / \mathrm{Ti}$ ratio in TS-1 decreased from 54.9 to 52.3 , and the Si/Al ratio in ZSM-5 decreased from 55.8 to 52.1 . This shows that desilication is even easier in ZSM-5 than it is in TS-1. However, for the Al-TS-1 samples, the $\mathrm{Si} / \mathrm{Ti}$ ratio was almost constant after treatment with alkali, whereas the $\mathrm{Si} / \mathrm{Al}$ ratio decreased from 55.9 to 52.1. We can see that the rule for extracting $\mathrm{Si}$ in Al-TS-1 is the same as that in ZSM-5. This clearly demonstrates that the presence of framework $\mathrm{Al}$ in Al-TS-1 inhibited desilication next to framework Ti species, and protected Ti from losing its tetrahedral state.

\section{Conclusions}

Al atoms can be incorporated into an MFI framework more easily than $\mathrm{Ti}$ atoms can in the process of doping Al heteroatoms into the TS- 1 framework. When the Al content in the starting material is higher than 0.005 , it will greatly influence the formation of framework Ti species. However, when the $\mathrm{Al} / \mathrm{Si}$ ratio is lower than 0.005 , the presence of $\mathrm{Al}$ does not influence insertion of Ti into the zeolitic framework and oxida- tion performance catalyzed by tetrahedral-state $\mathrm{Ti}$ species. Brönsted acid sites originating from framework Al species in Al-TS-1 can catalyze side reactions of 1,2-epoxyhexane with the methanol solvent in epoxidation of 1-hexene, but the presence of framework Ti species has no influence on the acid catalytic properties of framework $\mathrm{Al}$ species. In the ammoximation of cyclohexanone, desilication adjacent to Ti in Al-TS-1 is much more difficult than it is in TS-1. This could be used in the design of high-performance catalysts for ammoximation of cyclohexanone.

\section{References}

[1] Taramasso M, Perego G, Notari B. US Patent 4410 501.1983

[2] Ratnasamy P, Srinivas D, Knözinger H. Adv Catal, 2004, 48: 1

[3] Zhang S, Deng X J, Shen L, Liu Y M. Chin J Catal (张硕, 邓秀娟, 申 璐, 刘月明. 催化学报), 2012, 33: 723

[4] Wang D Q, Zhang Y B, Xiao D H, Yang X G. Chin J Catal (王德强, 张 一波, 肖德海, 杨向光. 催化学报), 2011, 32: 723

[5] Fang X Q, Wang Y N, Deng X J, Wu H H, Wu P, Liu Y M, He M Y. Chin J Catal (方向青, 王钰宁, 邓秀娟, 吴海虹, 吴鹏, 刘月明, 何鸣元. 催化学报), 2011, 32: 333

[6] Deng X J, Shen L, Zhang S, Liu Y M. Chin J Catal (邓秀娟, 申璐, 张 硕, 刘月明. 催化学报), 2011, 32: 1550

[7] Zhuo Z X, Lin L F, Deng X J, Wang Y N, Liu Y M. Chin J Catal (卓佐西, 林龙飞, 邓秀娟, 王钰宁, 刘月明. 催化学报), 2013, 34: 604

[8] Forni L, Pellozi M, Giusti A, Fornasari G, Millinit R. J Catal, 1990, 122: 44

[9] Thangaraj A, Kumar R, Sivasanker S. Zeolites, 1992, 12: 135

[10] On D T, Kaliaguine S, Bonneviot L. J Catal, 1995, 157: 235

[11] Ovejero G, Van Grieken R, Uguina M A, Serrano D P, Melero J A. Catal Lett, 1996, 41: 69

[12] Chu C T W, Chang C D. J Phys Chem, 1985, 89: 1569

[13] Bellussi G, Carati A, Clerici M G, Esposite A. Stud Surf Sci Catal, 1991, 63: 421

[14] Melero J A, van Grieken R, Serrano D P, Espada J J. J Mater Chem, 2001, 11: 1519

[15] Ovejero G, van Grieken R, Uguina M A, Serrano D P, Melero J A. J Mater Chem, 1998, 8: 2269

[16] Li H, Lei Q Zhang X M, Suo J Sh. Catal Commun, 2009, 10: 1936

[17] Sato T, Dakka J, Sheldon R A. J Chem Soc, Chem Commun, 1994, 1887

[18] On D T, Kapoor M P, Joshi P N, Bonneviot L, Kaliaguine S. Catal Lett, 1997, 44:171

[19] Li G, Wang X S, Yan H S, Liu M, Liu Y H, Chen Y Y. Chin J Catal (李钢,

\section{Graphical Abstract}

Chin. J. Catal., 2013, 34: 1232-1241 doi: 10.1016/S1872-2067(12)60553-1

\section{Synthesis and catalytic oxidation performance of Al-TS-1}

SHEN Lu, DENG Xiujuan, LIU Yueming *

East China Normal University

The preparation of TS-1 containing Al (Al-TS-1) and its catalytic oxidation properties have been investigated systematically. Neither the Al centers nor the Ti centers in the Al-TS-1 framework influence the acidic catalytic performance and catalytic oxidation performance.

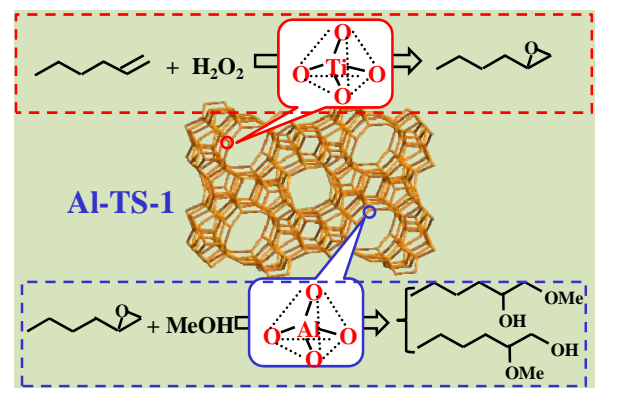


王祥生, 间海生，刘民，刘毅慧，陈永英. 催化学报)，2001，22: 465

[20] Clerici M G, Bellussi G, Romano U.J Catal, 1991, 129: 159

[21] Kuwahara Y, Nishizawa K, Nakajima T, Kamegawa T, Mori K, Yamashita H.J Am Chem Soc, 2011, 133: 12462

[22] Fan W B, Duan R G, Yokoi T, Wu P, Kubota Y, Tatsumi T. J Am Chem Soc, 2008, 130: 10150

[23] Serrano D P, Uguina M A, Ovejero G, van Grieken R, Camacho M,
Melero J A. J Mater Chem, 1999, 9: 2899

[24] van Grieken R, Serrano D P., Melero J A, Garcia A. J Mol Catal A, 2004, 222: 167

[25] Song F, Liu Y M, Wu H H, He M Y, Wu P, Tatsumi T. Chem Lett, 2005, 34: 1436

[26] Song F, Liu Y M, Wu H H, He M Y, Wu P, Tatsumi T. J Catal, 2006, 237: 359

[27] Jin F, Tian Y, Li Y D. Ind Eng Chem Res, 2009, 48: 1873

\title{
Al-TS-1的合成及催化氧化性能
}

\author{
申 璐, 邓秀娟, 刘月明* \\ 华东师范大学化学系, 上海市绿色化学与化工过程绿色化重点实验室, 上海200062
}

摘要: 系统研究了Al掺杂TS-1 (Al-TS-1)分子篎的合成及其催化氧化性能, 采用X射线衍射、紫外-可见光谱、电感耦合等离子体发 射光谱、扫描电镜、 ${ }^{27} \mathrm{Al}$ 和 ${ }^{29} \mathrm{Si}$ 固体核磁共振等手段对Al-TS-1样品进行了表征. 结果表明, 在合成过程中, Al的引入会影响TS-1中 骨架Ti的形成, 但当 $\mathrm{Al}$ 含量低于一定值 $(\mathrm{Al} / \mathrm{Si} \leqslant 0.005)$ 时, 其影响很小. Al-TS-1中骨架Al和骨架Ti均不对其相应的酸催化和催化 氧化作用产生影响. 骨架Al抑制了Al-TS-1在碱性应用体系中的与Ti相邻Si的溶脱, 从而保护了骨架Ti活性中心.

关键词: 铝掺杂TS-1分子篮; 合成; 氧化; 溶硅; 肜化

收稿日期: 2013-01-14. 接受日期: 2013-01-29. 出版日期: 2013-06-20.

*通讯联系人. 电话/传真: (021)62232058; 电子信箱: ymliu@chem.ecnu.edu.cn

基金来源：国家自然科学基金(20973064); 国家科技支撑计划(2012BAE05B02); 上海市科委基础研究重点项目(12JC14030600); 上海市重点学科建设项目(B409).

本文的英文电子版由Elsevier出版社在ScienceDirect上出版(http://www.sciencedirect.com/science/journal/18722067).

\section{1. 前言}

钛硅(TS-1)分子篮是纯硅沸石的同晶取代物, 自 1983年首次合成以来 ${ }^{[1]}$, 广泛应用于以 $\mathrm{H}_{2} \mathrm{O}_{2}$ 为氧化剂的 绿色有机催化领域中 ${ }^{[2 \sim 4]}$. 研究表明, TS- $1 / \mathrm{H}_{2} \mathrm{O}_{2}$ 体系催 化作用的基本历程是分子篎活性中心 $\mathrm{Ti}$ 首先活化 $\mathrm{H}_{2} \mathrm{O}_{2}$ 形成活性氧物种, 然后活化氧有效传递到底物, 进而完 成选择性氧化过程, 生成相应的氧化产物 ${ }^{[2,3,5 \sim 7]}$. TS-1分 子篮的结构特征, 如钛物种的配位状态、表面酸性和亲 疏水性及杂原子引入等, 均会对其催化性能产生影响. 其中杂原子掺杂的TS-1分子篮引起了人们的广泛关注. 如将三价杂原子(如 $\mathrm{B}, \mathrm{Al}, \mathrm{Fe}$ 等)引入到 TS-1 分子篎骨

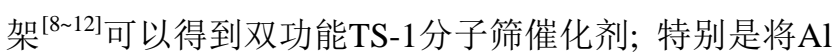
引入到TS-1分子篮骨架形成的Al-TS-1, 构建了 Brönsted 酸性位 ${ }^{[13 ~ 15]}$, 具有酸性/氧化性能的双功能催化特性, 在 醇的醚化等反应中表现出很好的催化性能 ${ }^{[11]}$. 诚然, 在 非碱性反应体系中, Brönsted酸性位的存在会发生催化 氧化的副反应 ${ }^{[16 ~ 19]}$.

实际上对于Al-TS-1分子篮, 研究者关注的深层次 问题是, 骨架 $\mathrm{Al}$ 和骨架 $\mathrm{Ti}$ 是否会相互影响其各自的催化 性能. Thangaraj 等 ${ }^{[9]}$ 研究表明, 由于 $\mathrm{Al}$ 的存在, 其分解 $\mathrm{H}_{2} \mathrm{O}_{2}$ 造成了 Al-TS-1催化苯羟基化反应活性降低, 但在
间二甲苯异构化反应中表现出与ZSM-5相似的催化性 能. 这说明Ti的存在并未影响Al-TS-1的酸催化性能, 而 $\mathrm{Al}$ 的存在则降低了其催化氧化性能. Ovejero等 ${ }^{[15]}$ 则认 为, 当 $\mathrm{Al} / \mathrm{Ti}=0.7$ 时, 由于 $\mathrm{Al}-\mathrm{TS}-1$ 表面亲疏水性的改变, $\mathrm{Al}$ 的存在提高了Al-TS-1的催化氧化性能. 这说明该问 题还未认识清楚, 特别是Al-TS-1中骨架Al对骨架Ti的催 化氧化性能究竟是否有影响的问题. 因此, 本文在系统 研究Al-TS-1分子篮合成的基础上, 对其结构特征进行 了详细表征, 并进一步研究其催化氧化性能. 研究表明, Al-TS-1分子篮中骨架Al的存在并没有影响骨架Ti的催 化氧化性能, 反之亦然. 进一步对Al-TS-1分子篎应用于 环己酮氨肟化反应的研究表明, $\mathrm{Al}$ 的存在抑制了反应过 程中由于与钛相邻硅的溶脱而造成的活性钛的流失. 这 对于设计在碱性体系中应用的高稳定性的TS-1分子篮 催化剂具有重要的指导意义.

\section{2. 实验部分}

\subsection{Al-TS-1的制备和表征}

采用水热法合成不同 $\mathrm{Al}$ 含量的Al-TS-1分子篮 ${ }^{[20,21]}$. 将异丙醇铝(AIP, AR, 国药集团化学试剂有限公司)溶解 到模板剂四丙基氢氧化铵(TPAOH, $w=25 \%$, 工业级产 品)的稀溶液中, 并缓慢滴入一定配比的正硅酸四乙酯 
(TEOS, AR, 国药集团化学试剂有限公司)和钛酸四丁酯 (TBOT, AR, 上海凌峰化学试剂有限公司)的混合液, 经 水解、赶醇, 于 $170{ }^{\circ} \mathrm{C}$ 水热晶化 $48 \mathrm{~h}$, 晶化产物抽滤、洗 涤、烘干和焙烧后得到Al-TS-1催化剂. 分子篮合成物料 摩尔配比为 TEOS:TBOT:AIP:TPAOH: $\mathrm{H}_{2} \mathrm{O}=1: 0.0167$ : (0.001 0.0167):0.18:18.

TS-1 的合成, 除不添加 AIP 外, 所有步骤均同 Al-TS-1.

采用Bruker D8 ADVANCE型X射线衍射 (XRD) 仪 $\left(\mathrm{Cu} K_{\alpha}\right.$ 射线, 扫描范围 $\left.2 \theta=5^{\circ} \sim 35^{\circ}\right)$ 测定晶相; 用 Shimadzu UV-2550型紫外-可见(UV-Vis)光谱仪 $\left(\mathrm{BaSO}_{4}\right.$ 为参照, 测试范围190 500 nm)表征Ti的状态; 用固体魔 角核磁共振谱(MAS-NMR)测定骨架 $\mathrm{Si}$ 、Al配位状态; 用 Thermo IR ISIntrepid II 型电感耦合等离子体发射(ICP) 光谱仪测定 $\mathrm{Ti}$ 含量; 用Hitachi S-4800型冷场高分辨率发 射扫描电子显微镜(SEM) 测定颗粒大小.

\section{2. 正己烯环氧化反应}

以50 ml圆底烧瓶为反应容器, 并连接冷凝管作为冷 凝装置, $60^{\circ} \mathrm{C}$ 水浴加热反应 $2 \mathrm{~h}$. 体系组成为: $0.05 \mathrm{~g}$ 分 子篮、 $10 \mathrm{mmol}$ 正已烯(反应底物)、10 $\mathrm{mmol} \mathrm{H}_{2} \mathrm{O}_{2}(\sim 30$ $\mathrm{wt} \%$ 水溶液)和 $10 \mathrm{ml}$ 甲醇(溶剂). 在Agilent GC7890A型 气相色谱仪 $(30 \mathrm{~m} \times 320 \mu \mathrm{m} \times 0.25 \mu \mathrm{m}$ DB-WAX毛细管 柱)上进行产物分析, 采用内标法(环已酮为内标)计算各 组分的量, 从而得到反应物的转化率和产物的选择性. 反应体系中剩余的 $\mathrm{H}_{2} \mathrm{O}_{2}$ 采用 $0.05 \mathrm{~mol} / \mathrm{L} \mathrm{Ce}\left(\mathrm{SO}_{4}\right)_{2}$ 溶液进 行滴定.

\section{3. 环己酮氨肟化反应}

环己酮氨肜化反应在配有回流冷凝器和微量进样 器的 $100 \mathrm{~mL}$ 三颈烧瓶中进行. 将 $0.45 \mathrm{~g}$ 催化剂, $30 \mathrm{mmol}$ 环己酮(AR), $51 \mathrm{mmol} \mathrm{NH}_{3} \cdot \mathrm{H}_{2} \mathrm{O}(\mathrm{AR}, 25 \%), 10 \mathrm{ml}$ 叔丁醇 和水的混合溶剂(叔丁醇( $\mathrm{AR}$ ) 质量含量 $85 \mathrm{wt} \%$ ), 一起加 入到三颈烧瓶中, 并将 $33 \mathrm{mmol} \mathrm{H}_{2} \mathrm{O}_{2}(\sim 30 \mathrm{wt} \%$ 水溶液) 以匀速在 $90 \mathrm{~min}$ 内滴加完毕, 反应温度 $75^{\circ} \mathrm{C}$, 磁力摚拌, 定时采样. 用Agilent GC7890A型气相色谱仪测定环己 酮的转化率和环己酮肜的选择性.

\section{3. 结果与讨论}

\subsection{Al-TS-1的合成与表征}

\subsubsection{XRD结果}

图 1 为不同 $\mathrm{Al} / \mathrm{Si}$ 比合成的 $\mathrm{Al}-\mathrm{TS}-1(\mathrm{Si} / \mathrm{Ti}=60)$ 的 XRD谱. 由图可知, 各Al-TS-1样品均具有典型的MFI结 构特征峰, 且结晶度良好, 表明Al的引入并未改变TS-1的

\section{MFI特征结构 ${ }^{[14]}$.}

\subsubsection{UV-Vis结果}

图 2 为由不同 $\mathrm{Al} / \mathrm{Si}$ 比合成的 $\mathrm{Al}-\mathrm{TS}-1(\mathrm{Si} / \mathrm{Ti}=60)$ 的 UV-Vis谱. 一般认为, $\lambda=210 \mathrm{~nm}$ 附近出现的吸收峰归 属于孤立的骨架Ti(IV)的特征峰; $\lambda=260 \mathrm{~nm}$ 附近的对 应于六配位非骨架钛的特征峰; $\lambda=330 \mathrm{~nm}$ 附近的归属 为锐钛矿物种的特征峰 ${ }^{[22]}$. 由图2可知, 各Al-TS-1样品 均在 $210 \mathrm{~nm}$ 处有强吸收峰, 说明其均具有较好的骨架 $\mathrm{Ti}(\mathrm{IV})$ 分布, 与文献结果一致 ${ }^{[11,15]}$. 但当 $\mathrm{Al} / \mathrm{Si}>0.005$ 时, 所合成的Al-TS-1 分子篮在 $\lambda=210 \mathrm{~nm}$ 处的峰强度明显 低于 $\mathrm{Al} / \mathrm{Si} \leqslant 0.005$ 样品及常规 TS-1的, 表明此时 $\mathrm{Al}$ 的存 在在一定程度上影响了 $\mathrm{Ti}$ 进入分子篮骨架. 另外, Al-TS-1和 TS-1均出现锐钛矿物种的特征峰, 且峰形相 似, 说明Al的引入并未影响Ti的分布状态.

\subsubsection{ICP结果}

图 3 为当投料 $\mathrm{Si} / \mathrm{Ti}=60$, 由不同 $\mathrm{Al} / \mathrm{Si}$ 比合成的 $\mathrm{Al}-\mathrm{TS}-1$ 分子篎经 ICP测得的 $\mathrm{Ti} / \mathrm{Si}$ 和 $\mathrm{Al} / \mathrm{Si}$ 比值. 由图可 知, 当 $\mathrm{Al} / \mathrm{Si} \leqslant 0.005$ 时, Al-TS-1的 $\mathrm{Ti} / \mathrm{Si}$ 比基本维持与常 规TS-1合成的水平, 即 $\mathrm{Al}$ 基本不影响 Ti插入分子篮骨架; 当 $\mathrm{Al} / \mathrm{Si}>0.005$ 时, 其 $\mathrm{Ti} / \mathrm{Si}$ 比则随着 $\mathrm{Al}$ 含量的增加而降 低, 说明此时 $\mathrm{Al}$ 阻碍了 Ti进入分子篮骨架. 而 $\mathrm{Al} / \mathrm{Si}$ 比则 呈现线性趋势, 说明 $\mathrm{Al}$ 几乎可以全部进入 $\mathrm{Al}-\mathrm{TS}-1$ 分子 䇻骨架. 这是因为AI比 Ti更容易进入MFI骨架. 若合成 体系中 $\mathrm{Al}$ 含量过多时, $\mathrm{Al}$ 会与 $\mathrm{Ti}$ 物种形成竞争关系, 抑 制Ti物种进入分子篎骨架 ${ }^{[11,15]}$, 从而导致Ti/Si比降低, 与 UV-Vis结果一致.

\subsubsection{SEM结果}

图4为由不同 $\mathrm{Al} / \mathrm{Si}$ 比合成的 $\mathrm{Al}-\mathrm{TS}-1(\mathrm{Si} / \mathrm{Ti}=60)$ 的 SEM照片. 由图可知, Al-TS-1样品均为椭球形颗粒, 但 颗粒尺寸均大于常规合成的 TS-1分子篮, 且随着合成体 系 $\mathrm{Al}$ 含量的增加而逐渐增大. 值得注意的是, 随着合成 体系 $\mathrm{Al}$ 含量的增加, $\mathrm{Al}-\mathrm{TS}-1$ 呈现出明显小粒子堆积现 象, 这说明 $\mathrm{Al}$ 在合成体系中有利于分子篮成核. 这和 Melero等 ${ }^{[14]}$ 和Serrano等 ${ }^{[23]}$ 在研究Al-TS-1的晶化机理时 提出的Al对晶化的影响一致.

\subsection{5. ${ }^{27} \mathrm{Al}$ 和 ${ }^{29} \mathrm{Si}$ MAS NMR谱}

图5(a)为由不同 $\mathrm{Al} / \mathrm{Si}$ 比合成的 Al-TS-1 (Si/Ti = 60) 的 ${ }^{27} \mathrm{Al}$ MAS NMR谱. 通常, $\delta=50$ 附近的吸收峰归属为 四配位骨架 $\mathrm{Al}$, 而 $\delta=0$ 附近的则对应于六配位的骨架外 八面体 $\mathrm{Al}$ 物种 ${ }^{[15]}$. 由图可知, 各Al-TS-1样品中均以四配 位骨架 $\mathrm{Al}$ 形式存在. 这表明 $\mathrm{Al}$ 确实比 $\mathrm{Ti}$ 更容易进入骨 架 ${ }^{[11,15]}$, 与 ICP结果一致. 图5(b)为由不同 $\mathrm{Al} / \mathrm{Si}$ 比合成的 
Al-TS-1 (Si/Ti = 60) 及 TS- 1 的 ${ }^{29} \mathrm{Si}$ MAS NMR谱. 通常认 为, $\delta=-104.0$ 处的 $\mathrm{Q}^{3}$ 为 $\mathrm{Si}$ 连接一个羟基, 通过氧原子连 接三个 $\mathrm{T}$ 原子的响应峰, $\delta=-115.0$ 处的 $\mathrm{Q}^{4}$ 为 $\mathrm{Si}$ 通过氧原 子连接四个 $\mathrm{T}$ 原子的响应峰. 可知, Al-TS-1和TS-1中 Si 均主要以 $\mathrm{Q}^{4}$ 形式存在, 且 $\mathrm{Al}$ 的存在及含量对骨架 $\mathrm{Si}$ 状态 的影响很小. 从 $\mathrm{Q}^{3}$ 峰的分析可知, 不同 $\mathrm{Al}$ 含量、相同 $\mathrm{Ti}$ 含量的Al-TS-1与相同 Ti含量的TS-1分子篮表面的亲疏 水性基本相当.

\subsection{Al-TS-1的催化氧化性能}

\subsection{1. 正己烯环氧化反应}

图6为由不同 $\mathrm{Al} / \mathrm{Si}$ 比合成的 $\mathrm{Al}-\mathrm{TS}-1(\mathrm{Si} / \mathrm{Ti}=60)$ 催 化正己烯环氧化反应结果. 由图可知, 反应产物中除了 环氧化反应产物环氧己烷外, 还有酸催化的环氧己烷与 溶剂的醇解反应产物醇醚, 但未检测到酸催化的水解产 物 1,2 -已二醇存在. 这可能是因为醇解反应比水解反应 更易进行 ${ }^{[16,24]}$.

由图6可见, 当 $\mathrm{Al} / \mathrm{Si} \leqslant 0.005$ 时, $\mathrm{Al}-\mathrm{TS}-1$ 样品的正己 烯转化率基本不变; 而当 $\mathrm{Al} / \mathrm{Si}>0.005$ 时, 正己烯转化率 随着分子篮中 $\mathrm{Al}$ 含量的增加而稍有下降, 这是由于高 $\mathrm{Al}$ 含量Al-TS-1中活性中心 Ti物种相对较少所致. 然而, 随 $\mathrm{Al}$ 含量的变化正己烯转化的 $\mathrm{TON}$ 值均较高; 同时, $\mathrm{H}_{2} \mathrm{O}_{2}$ 有效利用率也较高. 这说明Al-TS-1中骨架Al的存在并 未影响骨架 Ti活性中心的催化氧化性能. 李钢等 ${ }^{[19]}$ 对 TS-1中Al杂质对其催化丙烯环氧化性能的影响进行了 研究, 发现, 只要碱中和了其中的酸性位, 环氧丙烷转化 率就不受影响. 这说明尽管在合成过程中, 当 $\mathrm{Al}$ 含量较 高时会影响Ti进入Al-TS-1分子篮骨架, 但骨架Al并未影 响骨架 $\mathrm{Ti}$ 的催化氧化性能, 与文献 $[9,15]$ 报道不同. Thangaraj等 ${ }^{[9]}$ 认为, Al-TS-1中Al的存在导致了 $\mathrm{H}_{2} \mathrm{O}_{2}$ 的分 解, 而真实的原因可能是大量的非骨架 $\mathrm{Ti}$ 造成的. 因为 在 $\mathrm{Si} / \mathrm{Ti}=24, \mathrm{Si} / \mathrm{Al}=45$ 时, 如此高的 $\mathrm{Al}$ 含量, $\mathrm{Ti}$ 不可能完 全进入骨架, 因此一部分 $\mathrm{Ti}$ 是以非骨架形式存在. 而 Ovejero等 ${ }^{[15]}$ 认为, 当 $\mathrm{Al} / \mathrm{Ti}=0.7$ 时, 由于 $\mathrm{Al}-\mathrm{TS}-1$ 表面亲 疏水性的改变, 提高了它在Al-TS-1在烷烃氧化反应中 的催化性能. 而由图5(b) 可知, 不同骨架 $\mathrm{Al}$ 含量的 Al-TS-1表面亲疏水性与 TS-1分子篮基本相当, 它们的 催化氧化性能差别也不大. 因此, 骨架 $\mathrm{Al}$ 不会明显影响 Al-TS-1骨架Ti的催化氧化性能.

对于Al-TS-1的酸催化作用来说, 从醇解反应产物 醇醚的选择性变化趋势可知, 其随着 $\mathrm{Al}$ 含量的增加而线 性增加, 而环氧化产物的选择性的变化却线性下降. 这 说明, Al-TS-1中骨架Ti的存在确实也没有影响其酸催化
性能, 与文献[9]报道一致.

\subsection{2. 环已酮氨肟化反应}

\subsubsection{Al-TS-1的初始活性}

图7为由不同 $\mathrm{Al} / \mathrm{Si}$ 比合成的 $\mathrm{Al}-\mathrm{TS}-1(\mathrm{Si} / \mathrm{Ti}=60)$ 催 化环己酮氨肟化反应结果. 可知, $\mathrm{Al}$ 含量对环己酮的转 化率和环已酮肜的选择性基本无影响. 这说明在碱性催 化体系中, Al引入TS-1骨架并不影响分子篮骨架Ti的催 化氧化性能, 与Al-TS-1催化正己烯环氧化反应结果一 致. 虽然 $\mathrm{Al}$ 的存在引入了Brönsted酸性位, 但体系中过 量 $\mathrm{NH}_{3}$ 的存在中和了分子篎酸性位 ${ }^{[19]}$, 因而未对催化剂 的催化氧化性能产生不利影响.

\subsubsection{Al-TS-1的重复使用性}

图 8 为 $\mathrm{Si} / \mathrm{Al}=100, \mathrm{Si} / \mathrm{Ti}=60$ 合成的 $\mathrm{Al}-\mathrm{TS}-1$ 上环己 酮氨肟化反应的重复性能. 可知, Al-TS-1和TS-1 (Si/Ti $=60)$ 表现出了相当的催化氧化性能. 重复使用8次后, 其活性降低. 失活催化剂经 $550^{\circ} \mathrm{C}$ 焙烧后, 其活性又恢 复恢复到初始水平.

为了进一步分析Al-TS-1在环己酮氨肜化反应过程 中结构的变化, 实验对Al-TS-1和TS-1在循环使用前后 进行了XRD和ICP测试, 结果如图9和表1所示.

图9(a)和(b)分别为Al-TS-1和TS-1重复使用不同次 数后的XRD谱. 可知, 在重复使用中Al-TS-1和TS-1均保 持了完好MFI结构. 由表1可知, TS-1重复使用后, 其 $\mathrm{Si} / \mathrm{Ti}$ 比从51.1升至52.1. 这说明反应过程中溶硅的速率 小于源于溶 $\mathrm{Si}$ 而导致的 $\mathrm{Ti}$ 的脱除速率, 因而 $\mathrm{Si} / \mathrm{Ti}$ 比升 高 ${ }^{[25,26]}$. 然而, Al-TS-1重复使用后, 其Si/Ti比从59.9降至 59.4. 这表明Al-TS-1在重复使用过程中Ti的脱除有所抑 制. 另外, Si/Al比从 86.3降低至81.6, 意味着Al-TS-1在重 复使用过程中溶硅的速率大于源于溶 $\mathrm{Si}$ 而导致的 $\mathrm{Al}$ 的 脱除速率. 因此, 对于Al-TS-1而言, 在催化环己酮氨弜 化反应过程中, 分子篮骨架中与 $\mathrm{Al}$ 相邻的 $\mathrm{Si}$ 比与 $\mathrm{Ti}$ 相邻 的 $\mathrm{Si}$ 更容易受到碱的攻击而溶脱, 从而有利于钛硅分子 節骨架Ti的保持.

\subsubsection{3. $\mathrm{Si}$ 与 $\mathrm{Ti}$ 的脱出规律}

为了进一步验证Al-TS-1的碱溶硅规律, 本文采用 $\mathrm{NaOH}$ 水溶液分别处理了 TS-1, ZSM-5 以及 Al-TS-1 ${ }^{[27]}$, 并用 ICP分析相应的 $\mathrm{Si} / \mathrm{Ti}$ 比和 $\mathrm{Si} / \mathrm{Al}$ 比在处理前后的变 化, 结果示于表2. 可以看出, 经 $\mathrm{NaOH}$ 处理后, TS-1的 Si/Ti比从54.9降至52.3, ZSM-5的Si/Al比从55.8降至52.1. 这说明在相同条件下, ZSM-5中的Si比TS-1中的更易受 碱溶硅而脱除. 然而, Al-TS-1的 Si/Ti比基本不变, 而 $\mathrm{Si} / \mathrm{Al}$ 比从 55.9 降至 52.1 , 说明 $\mathrm{Si}$ 的脱除规律与 ZSM-5的 
一样. 这进一步表明, Al-TS-1中骨架Al的存在, 确实能 够抑制与 $\mathrm{Ti}$ 相邻的 $\mathrm{Si}$ 的脱除, 从而保护了 TS-1 分子篮在 使用过程中Ti的流失.

\section{4. 结论}

在TS-1骨架中引入杂原子Al的过程中, 由于Al更容 易进入 MFI分子篮骨架, 当 $\mathrm{Al} / \mathrm{Si}>0.05$ 才会影响骨架 $\mathrm{Ti}$
的形成. 骨架Al的存在并未影响Al-TS-1分子篮表面亲 水性和骨架 $\mathrm{Ti}$ 的催化氧化性能; 但因此而形成的 Brönsted酸性位促进了烯烃氧化产物的开环反应; 同时, 骨架Ti的存在不影响骨架Al的酸催化反应性能. 在环己 酮氨肜化反应中, Al-TS-1较TS- 1 具有更好的抑制与 Ti相 邻的 $\mathrm{Si}$ 的溶脱. 该结果对于设计高性能环己酮氨肜化催 化剂具有一定的指导意义. 